\title{
Logistics Service Type, Firm Size and the Reasons for Keeping Green Mindfulness - A Theoretical Framework
}

\author{
Yi-Hui Ho, Chieh-Yu Lin* \\ Department of International Business, Chang Jung Christian University, Taiwan
}

Copyright $(2019$ by authors, all rights reserved. Authors agree that this article remains permanently open access under the terms of the Creative Commons Attribution License 4.0 International License

\begin{abstract}
To pursue sustainable development, integration of environmental concepts and business operations has become a fundamental part of value creation strategy. Environmental management has received sustained research interest over time. Organizational green mindfulness is a way of organizational attitude during environmental management marked by preoccupation with failure, reluctance to simplify interpretations, sensitivity to operations, commitment to resilience, and deference to expertise. The study expects that firms should keep mindfulness thinking while engaging in environmental management. The main purpose of this study is to propose a theoretical framework exploring the moderating effects of logistics service type and firm size on the reasons for keeping green mindfulness. The reasons proposed in the study include economic reason and social reason. Logistics service type and firm size would moderate the influences of economic reason and social reason on keeping green mindfulness.
\end{abstract}

Keywords Logistics Service Type, Firm Size, Green Mindfulness, Economic Reason, Social Reason

\section{Introduction}

While environmental issues have become critical concerns all over the world, firms are constantly under pressure to develop environmentally responsible and friendly operations (Arend, 2014; Christmann \& Taylor, 2002; Husted, 2005). Commitment to the natural environment has become an important variable within the current competitive scenarios while companies worldwide are continuously trying to develop new and innovative ways to enhance their global competitiveness. There is a remarkable increase in both interests and reactions to the concept of preserving the environment in recent years. This has been attributable to the life-threatening of global ecosystem deterioration, the pressure from consumers, and the increasing statutory requirements of government policies and regulations (Buysse \& Verbeke, 2003; Corbett \& Kleindorfer, 2001; Gonzalez-Benito \& Gonzalez-Benito, 2006). Many firms have implemented environmental management practices to enhance their competitiveness through improvements in their green performance to comply with mounting environmental regulations, to mitigate the environmental impact of their business activities, and to address the environmental concerns of their customers.

Implementation of environmental management constitutes a complex information processing and decision making scenario that involves making sense of a new green concept or practice that the firm is unfamiliar with and is typically characterized by uncertainty and ambiguity over the outcomes of the implementation process (AragonCorrea \& Sharma, 2003; Christmann \& Taylor, 2006; Winn \& Angell, 2000). Although firms can achieve considerable environmental performance by successfully implementing environmental practices into their work systems, they may fail to achieve deep usage beyond initial adoption because engaging in environmental management often constitutes complex technologies and processes and calls for significant investment of organizational resources. Successful implementation of environmental management requires significant involvement in developing operational responses to environmental issues (Christmann \& Taylor, 2006; Fussel \& Georg, 2000; Prajogo, Tang \& Lai, 2014). Thus, managers are faced with the task of analyzing the ramifications of the green concepts or practices on their firms (Sonenshein, DeCelles \& Dutton, 2014; Wals \& Schwarzin, 2012). Under such circumstances, firms require mindfulness thinking in the implementation of environmental management (Ho \& Lin, 2014b; Wals \& Schwarzin, 2012). Deciding on whether a particular green concept or practice is a good thing for the firm, whether the 
timing of the implementation is appropriate, and how the implementation is best carried out requires firms to be mindful of engaging in environmental management with reasoning grounded in their own facts and specifics (Fussel \& Georg, 2000; Jenkin, McShane \& Webster, 2011; Ranerjee, 2011).

Mindfulness is a state of being alert and aware in organizational decision-making. It is a characteristic that is believed to aid in making contextually differentiated interpretations of situations and information scenarios (Ndubisi, 2012b; Weick \& Sutcliffe, 2006). The mindfulness approach recognizes the value of managerial flexibility in structuring and timing investment decisions on the face of uncertain conditions, varying levels of risks at different stages of an investment project and irreversible investments (Fiol \& O'Connor, 2003; Ndubisi, 2012b). Accordingly, mindfulness theory is deemed suitable for application to the investigation of a firm's implementation of environmental management, more specifically when a green concept or practice is relatively new and uncertain in terms of its likely outcomes and managers have the flexibility of timing the implementation decision depending on factors such as prevailing market conditions and availability of information (Fichman, 2004; Weick \& Sutcliffe, 2006). Firms need to keep green mindfulness when engaging in environmental management. As a result, it is necessary to understand the issues about green mindfulness in environmental management. Although mindfulness has been considered by researchers across different disciplines and subjects, the concept of mindfulness has been scarcely employed in research on environmental management in the literature (Ho \& Lin, 2014b). To fill the research gap, this study attempts to explore the motives for keeping green mindfulness in firms.

With the rapid development of the green supply chain management, the importance of green management for the logistics industry has increased dramatically (Ramanathan, Bentley \& Pang, 2014; Skjoett-Larsen, 2000). To deliver products and services to customers more environmentally, logistics companies need to address more efforts on environmental issues (Murphy \& Poist, 2003; Sarkis, Meade \& Talluri, 2004). Logistics may represent up to 95\% of total costs in recycling (Stock, 1998). As environmental considerations have become a fundamental part of logistics companies' operations strategies, there is a challenge for logistics practitioners and academicians to examine the integration of green concepts and logistics operations through business strategy. Such integration can be regarded as green logistics practices which consist of new or modified processes, techniques, systems and products to avoid or reduce environmental damage when logistics services are provided. The logistics companies should reconstruct their logistics system to provide quick, environmentally-friendly logistics services.

The logistics company is a provider of logistics services that performs all or part of a client company's logistics functions including transportation, warehousing, packaging, and information flow (Coyle, Bardi \& Langley, 2003; Delfmann, Albers \& Gehring, 2002). As the rapid growth of concerns on environmental issues leads to a dramatic rise in green supply chain, logistics companies should pay more attention on green technologies and management systems to provide environmentally-friendly services (Lin \& Ho, 2011; Kudla \& Klaas-Wissing, 2012; McKinnon, 1995; Murphy \& Poist, 2000; Murry, 2007; Skjoett-Larsen, 2000). To benefit green supply chain management, logistics companies should introduce environmental concepts into their logistics operations by adopting green management practices which consists of a variety of processes, technologies, systems and products to avoid or reduce environmental damage (Colicchia, Marchet, Melacini \& Perotti, 2013; Hellstrom, 2007; Henriques \& Sadorsky, 2007) when logistics services are provided. To advance the adoption of green management practices for the logistics companies, it is necessary to draw a picture of green management practices for the logistics industry. Inman (2002) reviewed the implications of green management for operations management and came up with a list of research questions; among these, Inman (2002) has suggested three research question related to logistics operations: "how do transportation managers and warehouse managers account for the two-way flow of materials brought about by environmental management techniques?," "how do distributors facilitate grading and sorting of used materials?," and "how do operations managers define a general framework for logistics strategy altered by the inclusion of environmental management techniques?” Therefore, the professional and academic request for research on environmental management for the logistics industry leads to the rationale of this study.

This study focuses on the logistics industry because many logistics operations often lead to several negative environmental impacts, including air pollutants, waste disposal, and fuel consumption. The prevalence of green concepts derives the need for implementing green practices in the logistics industry. Logistics companies need to address much effort on environmental issues (Maas, Schuster \& Hartmann, 2014; Sarkis, Meade \& Talluri, 2004; Thai, Cahoon \& Tran, 2011). It is necessary to determine the logistics industry's peculiarities in their determination to face the environmental management problems, as well as to suggest useful mechanisms for it. Furthermore, although there is a burgeoning body of literature concerning with environmental issues in a variety of business disciplines such as manufacturing and marketing, the corresponding literature involving logistics has been still small but expanding (Demir, Bektas \& Laporte, 2014; Gunasekaran \& Cheng, 2008; Lin, 2011; Marchet, Melacini \& Perotti, 2014).

In summary, the main purpose of this study is to propose a theoretical framework analyzing the reasons for keeping 
green mindfulness in logistics companies. As to the structure of the paper, the next section illustrates the theoretical backgrounds of organizational green mindfulness and. The third section introduces the reasons for keeping green mindfulness, and the fourth section discuss the moderating effects of logistics service type and firm size. The final section gives research conclusions.

\section{Organizational Green Mindfulness}

In a study of high reliability organizations, Weick and Sutcliffe (2001) addressed that the mindfulness approach reflects the fact that many disasters are caused not by the presence of a large, catastrophic error but rather by the unfortunate combination of small ones. Mindfulness denotes that the ability of individuals and organizations to achieve reliable performance in a changing environment depends on how individuals and organizations think, gather information and perceive the world around them, and on whether they are able to change their perspective to reflect the situation. Weick and Sutcliffe (2001) identified five characteristics that underlie organizational mindfulness including preoccupation with failure, reluctance to simplify interpretations, sensitivity to operations, commitment to resilience, and deference to expertise. They found that, following the five characteristics, high reliability organizations can successfully operate under risky and complicated conditions and avoid failures and accidents. Mindfulness requires a desire to update situational awareness on a continuing basis, to cast doubt, and to probe further to resolve doubtfulness. Although normal business operations are carried out by firms under significantly less stringent conditions than high reliability organizations, inculcating the five characteristics in their organizational operations can reduce chances of failure by avoiding errors in the first place (Weick \& Sutcliffe 2001). Thus, mindfulness can be thought of as a desirable property or state that all firms, irrespective of their line of operation should strive to achieve, since it will make them more adept in managing unexpected circumstances (Ndubisi, 2012b; Ray et al., 2011).

Organizational mindfulness has been used to study organizational engagement with innovations (Fichman, 2004; Fiol \& O’Connor, 2003; Swanson \& Ramiller, 2004; Valorinta, 2009; Wolf et al., 2012). Mindful firms encourage people to report all errors, near misses, and improvement opportunities and to treat them as systemic issues rather than individual events. Environmental management implemented in firms is often characterized by new and complex technical knowledge and process changes, resulting in unexpected or uncertain outcomes. Applying environmental criteria into corporate operations requires exploring new resource combinations and deploying existing resources in new ways. Undertaking environmental management sometimes involves using new or modified processes and techniques to reduce environmental harms, and can be regarded as an organizational innovation process (Hellstrom, 2007; Henriques \& Sadorsky, 2007; Lin \& Ho, 2011). When engaging with an innovation, mindfulness pertains to attending to the innovation with a contextually differentiated reasoning based on the firm's own facts and specifics (Swanson \& Ramiller, 2004). Therefore, mindfulness in the context of environmental management refers to not only being knowledgeable about the green concept or practice and its implications, but also being able to contextualize this understanding regarding the concept or practice based on the specific circumstances prevailing in the firm and their implications on the implementation.

According to above discussions on the mindfulness concept, we hold that mindfulness concept is also suitable for environmental management. Mindfulness in environmental management, here denoted as green mindfulness, is a way of working during environmental management marked by a focus on the present, attention to operational detail, willingness to consider alternative perspectives and an interest in investigating and understanding failures (Langer, 1989; Weick \& Sutcliffe, 2001). Green mindfulness can also be discussed at the individual and organizational levels. At the individual level, green mindfulness can be conceptualized as a cognitive green ability that is reflected by openness to novelty, alertness to distinction, sensitivity to different contexts, awareness of multiple perspectives, and orientation in the present (Langer, 1997; Sternberg, 2000). At the organizational level, green mindfulness can be conceptualized as a cognitive green ability that is reflected by preoccupation with failure, reluctance to simplify interpretations, sensitivity to operations, commitment to resilience, and deference to expertise (Weick \& Sutcliffe, 2001).

With regard to environmental management, mindful firms who are preoccupied with failure, sensitivity to operations, and deference to expertise will pay more attention to the potential pitfalls associated with implementing new green concepts or practices as they appear. Mindful firms are more likely to empower knowledgeable team members allowing them to deal with an incipient problem and act on emerging opportunities. Also, they will be more likely to recognize problems not as isolated events that must be dealt with simply to maintain current operations, but rather as indicative of system issues that provide opportunities for further engagement in environmental management (Schultze \& Orlikowski, 2004). Taking together these aspects of organizational mindfulness prepare a firm to be better able to manage both the initial introduction and subsequent implementation of environmental management practices.

Likewise, successful environmental management is often the result of not a single large project or decision, but the outgrowth of a fortuitous combination of many small 
ones (Aragon- Correa \& Sharma, 2003; Henriques \& Sadorsky, 1999). Small disruptions, errors, and opportunities are most likely to be noticed first on the front lines of the firm where individuals involved with a firm's day-to-day operations reside. If these unexpected situations are dealt with swiftly, there is an opportunity to avoid their escalation into larger problems or to leverage them to facilitate change. Firms need to keep green mindfulness when engaging in environmental management. Mindfulness is likely to have implication in environmental management because the decision of evaluating and adopting green concepts or practices underlines a firm's attempt to make sense of something that is uncertain and can result in unexpected outcomes.

\section{Reasons for Keeping Green Mindfulness}

A variety of reasons for environmental management have been proposed in the literature. In general, the types of reasons can be classified into two groups as economic and social reasons. The economic reason refers to engaging in environmental management to improve organizational and market performance, whereas the social reason refers to engaging in environmental management to create social influence on others (Molla \& Abareshi, 2012; Wiengarten et al., 2013).

\subsection{The Relationship between Economic Reason and Keeping Green Mindfulness}

Several studies have suggested that economic reason, including cost saving and market expansion, is one reason why businesses engage in environmental management (Bronn \& Vidaver-Cohen, 2009; Gonzalez-Benito \& Gonzalez-Benito, 2005; Gilley, Worrell \& El-Jelly, 2000; Quazi, Khoo, Tan \& Wong, 2001; Uecker-Mercado \& Walker, 2012; Wiengarten et al., 2013). Many businesses have already realized cost saving by cutting resource use and waste generation. Examples of environmental management consist of adopting technology that allows for lower production and service costs and strengthens the financial benefits of environmental management (e.g., cost savings, reducing risks, tax incentives, etc.). Market expansion stems from the concern that business unit carries with it expected customer demand. Customers are becoming active in seeking information regarding the sustainability policies of businesses (Bronn \& Vidaver-Cohen, 2009). When companies implement environmental management, there are opportunities to increase sales and improve market position, that is, there are advantages derived from the differentiating power of environmental awareness. This is mainly due to the fact that environmentally proactive companies generate affective feelings from ecologically committed customers and build up a reputation (Russo \& Fouts, 1997). Firms with higher levels of environmental performance (i.e., success in reducing and minimizing environmental impact) would be rewarded through superior financial performance (Gilley et al., 2000). For example, UPS's adoption of an energy information system has reduced not only fuel consumption and cost but also emissions. Further, UPS has reduced trucks' mileage, and maintenance costs as the gathered information in its trucks are exploited to advance the company's sustainability objectives (Watson, Boudreau \& Li, 2010).

In addition to pinpointing opportunities for cost saving in the areas of raw materials, energy efficiency, and waste minimization or elimination of pollution, implementing environmental management can also make a good business better, maintaining good public relation and enhancing image and market share (Quazi et al., 2001). To a great extent, the rationality of this reasoning rests on the growing customers concern about the natural environment (Wiengarten et al., 2013). The stronger the firm's belief that environmental management can stimulate demand and improve market position, the higher the probability that the firm will keep green mindfulness. Therefore, from the perspective of cost saving and market expansion, keeping green mindfulness is motivated by the economic reason. This study expects that

Proposition 1: Economic reason has a positive effect on keeping green mindfulness.

\subsection{The Relationship between Social Reason and Keeping Green Mindfulness}

The adoption of environmental initiatives by a firm can be as a result of its concern for its social obligations and values (Bansal \& Roth, 2000). Social reason is another reason widely discussed in the studies about why businesses engage in environmental management (Bansal \& Rothe, 2000; Bronn \& Vidaver-Cohen, 2009; Gonzalez-Benito \& Gonzalez-Benito, 2005; Graafland \& Mazereeuw-Van der Duijn Schouten, 2012; Molla \& Abareshi, 2012; Quazi et al., 2012; Uecker-Mercado \& Walker, 2012; Wiengarten et al., 2013). Green mindfulness can be a consequence of both a truly ecological awareness on the part of the decision-makers and a desire to improve their environmental performance. Ethical consideration stems from the concern that business unit carries with it expected social obligations and values that contribute the society. For this kind of firm, the implementation of environmental management can be seen as a first solid step to achieving an improvement on performance, because it establishes a framework in which different environmental initiatives can be developed in a coordinated and controlled way. Such firms do not specifically focus on the bottom-line or return on investment but rather focus on how their decisions affect the organization and the community. The decision to keep 
green mindfulness responds to ethical consideration. the stronger the firm's belief that the achievement of social obligation is necessary, the higher the probability that the firm will keep green mindfulness

Furthermore, the political pressure comes from government regulations, standards and taxes whereas the social pressure comes from the institutional environment within which a firm operates. Firms engage in environmental management when they face regulatory and social pressures that threaten their legitimacy (Wiengarten et al., 2013). Firms carry out activities to satisfy their main stakeholders. Environmental consciousness of a firm implies harmonizing green performance with stakeholders' expectations. Under the circumstance of high stakeholder pressure, firms are apt to be reluctance to simplify interpretations of stakeholders' varied environmental requirements, and to keep commitment to resilience. Therefore, this study expects that

Proposition 2: Social reason has a positive effect on keeping green mindfulness.

\section{Moderators for Keeping Green Mindfulness}

\subsection{Moderating Effect of Firm Size}

An amount of empirical studies reveal a significant relationship between company size and the implementation of green management practices (e.g. Arend, 2014; Etzion, 2007; Gonzalez-Benito \& Gonzalez-Benito, 2006; Nejati et al., 2014; Wassmer et al., 2014). Firm size is repeatedly taken as a relevant organizational characteristic influencing a firm's environmental activities. In general, large firms tend to pay more efforts in implementing environmental management than small ones because large firms have more resource availability to devote to green management. Their scale allows them to face the indivisibilities associated with green management, that is those required investments in technology, human resources or certifications, which are similar for all the companies regardless of their size. The environmental efforts of large firms have a positive impact on a larger number of customers. Large firms usually receive more pressure from their social and economic environment and are frequently the primary objective of local governments and environmental nongovernmental organizations (Gonzalez-Benito \& Gozzlez-Benito, 2006). Therefore, the effects of economic and social reasons on keeping green mindfulness for large firms will be stronger than the effects for small firms. This study expects that

Proposition 3: Firm size will enhance the effects of economic and social reasons on keeping green mindfulness.

\subsection{Moderating Effect of Logistics Service Type}

Logistics companies provide a variety of logistics service activities for their customers, including warehousing, transportation, material handling, packaging, order processing, and so on. According to the primary logistics service provided for customers, logistics companies can be classified into several types: transportation-based, warehouse/distribution-based, forward-based, financial-based, and information-based logistics companies (Coyle, Bardi \& Langley, 2003). Because each logistics activity has a different polluting potential, different types of logistics companies may be subject to different controls and scrutiny from institutions, social groups and consumers (Murphy \& Poist, 2000; Oberhofer \& Dieplinger, 2014; Wu \& Dunn, 1995). For example, the transportation service may be associated with the poorest green performance and the greatest environmental risk. At the other extreme, order processing usually represents a reduced environmental impact and the lowest environmental risk. It is likely that firms in more regulated industries will embed environmental issues into their management strategies to a greater extent than those in less regulated industries because the negative consequences of noncompliance will tend to be significantly higher (Henriques \& Sadorsky, 1999). This led to think that in each service type there will be different attitudes toward environmental management. Therefore, the effects of economic and social reasons on keeping green mindfulness will be different for different types of logistics companies. This study expects that

Proposition 4: Logistics service type will moderate the effects of economic and social reasons on keeping green mindfulness. 


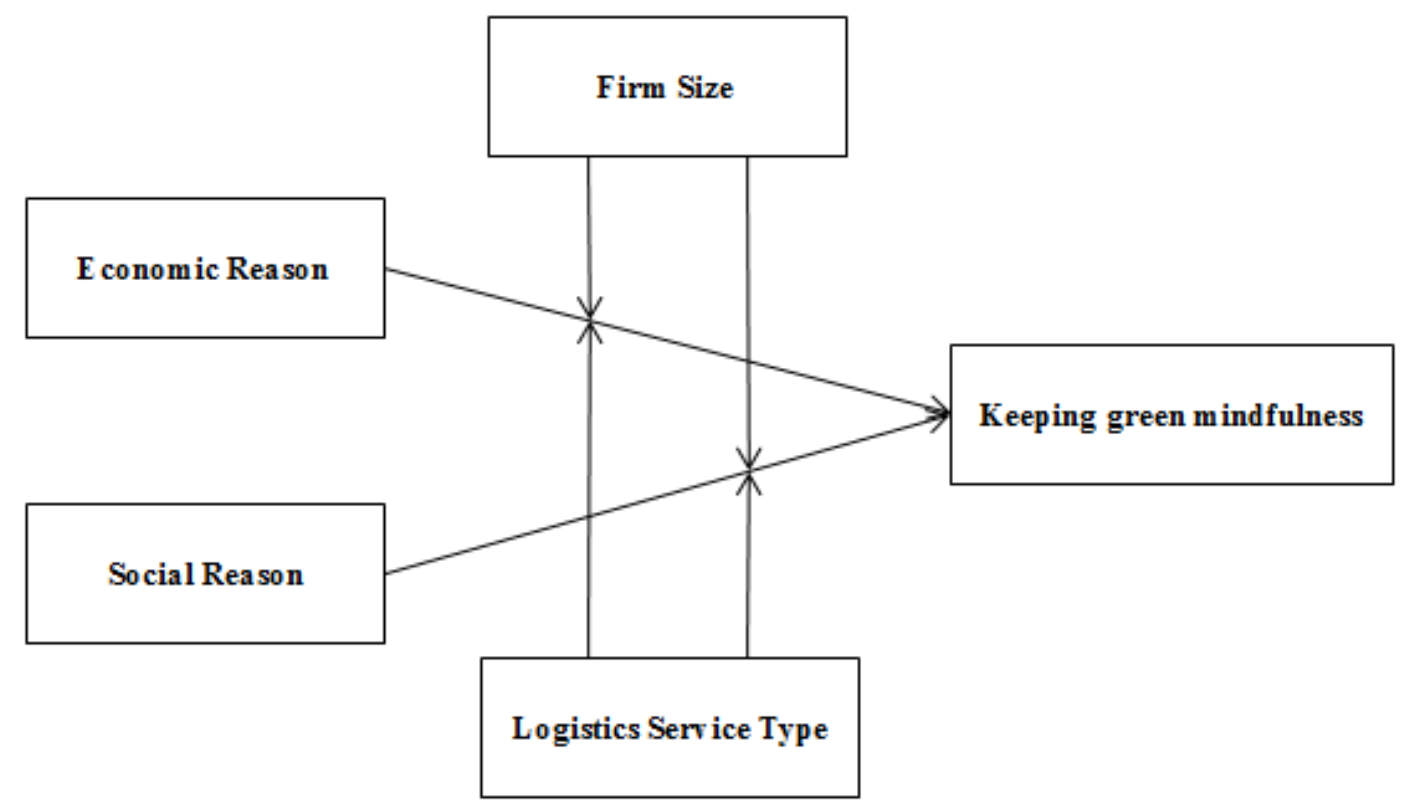

Figure 1. Theoretical Framework

\section{Conclusions}

Drawing on the literature of mindfulness, the study defines green mindfulness as a way of working during environmental management marked by a focus on the present, attention to operational detail, willingness to consider alternative perspectives and an interest in investigating and understanding failures. Undertaking environmental management is generally believed to impart strategic and competitive benefits to the firms. However, it also involves significant resource commitments on behalf of the firm. Chances of failing to successfully implement environmental management or to appropriate business value from it are often quite high. Thus, firms are faced with a complex scenario of deciding to implement a green concept or practice that is relatively new and uncertain in terms of expected outcomes, but calls for large resource investments on the firm's behalf, or embrace the risk of becoming saddled with outdated technology, and losing the flexibility to deploy new environmental capability when the market conditions call for.

Environmental management may be introduced with a great enthusiasm; nevertheless, it may fail to be thoroughly deployed among many firms. Firms need to keep green mindfulness when engaging in environmental management. It is necessary to understand the issues about organizational mindfulness of green practice implementation within organizations. While an increase in the number of environmental management articles appears in the literature, there is still lack of research focusing on utilizing the mindfulness concept in environmental management. This study proposes a theoretical framework regarding the reasons for keeping green mindfulness as well as the moderating effects of logistics service type and firm size, as shown in Figure 1.
Environmental management needs changes in routines and operations and has been identified as an organizational competence, since it requires the complex coordination of several human and technical skills and heterogeneous resources to reduce environmental impacts and simultaneously maintain or increase firm competitiveness. Implementing environmental management strategies requires knowledge and application of environmental management tools. Knowledge is an important mediator to promote sustainability management. As mindfulness is a characteristic that is believed to aid in making contextually differentiated interpretations of situations and information scenarios, firms require mindfulness thinking in environmental management. Mindfulness in the context of environmental management refers to not only being knowledgeable about the green concept or practice and its implications, but also being able to contextualize this understanding regarding the concept or practice based on the specific circumstances prevailing in the firm and their implications on the implementation. Mindfulness is likely to have implication in environmental management because the decision of evaluating and adopting green concepts or practices underlines a firm's attempt to make sense of something that is uncertain and can result in unexpected outcomes.

The organizational mindfulness approach recognizes the value of managerial flexibility in structuring and timing investment decisions on the face of uncertain conditions, varying levels of risks at different stages of an investment project and irreversible investments. This study attempts to explore the application of organizational mindfulness concept in environmental management for the logistics industry, and analyzing the effects of economic and social reasons on keeping green mindfulness. Understanding economic and social reasons for keeping green 
mindfulness is essential for practitioners to best implement environmental management as well as for researchers to best understand the issues that need to be addressed. Due to the lack of research on organizational mindfulness in green practice implementation, this study can broaden the scope of research on environmental management by clarifying the meanings of organizational mindfulness in green practice implementation, and providing some explanations as to the reasons why companies keep organizational mindfulness when deciding on implementing green practices.

Organizational mindfulness theory is deemed suitable for application to the investigation of green practice implementation, more specifically when a green practice is relatively new and uncertain in terms of its likely outcomes; and managers have the flexibility of timing the implementation decision depending on factors such as prevailing market conditions and availability of information. The present study only considers the economic and social reasons that have been widely used in the literature of environmental management. The influences of other possible reasons and moderators on logistics companies' organizational mindfulness in green practice implementation can also be taken into consideration in future studies.

\section{REFERENCES}

[1] Aragon-Correa, J. A., \& Sharma, S. (2003). A contingent resource-based view of proactive corporate environmental strategy. Academy of Management Review, 28(1), 71-88.

[2] Arend, R. (2014). Social and environmental performance at SMEs: considering motivations, capabilities, and instrumentalism. Journal of Business Ethics, 125(4), 541-561.

[3] Armstrong, J. S., \& Overion, T. S. (1977). Estimating nonresponse bias in mail surveys. Journal of Marketing Research, 14(3), 396-402.

[4] Bansal, P., \& Roth, K. (2000). Why companies go green: A model of ecological responsiveness. Academy of Management Journal, 43(4), 717-736.

[5] Bronn, P. S., \& Vidaver-Cohen, D. (2009). Corporate motives for social initiative: legitimacy, sustainability, or the bottom line? Journal of Business Ethics, 87(1), 91-109.

[6] Buysse, K., \& Verbeke, A. (2003). Proactive environmental strategies: a stakeholder management perspective. Strategic Management Journal, 24(5), 453-470.

[7] Christmann, P., \& Taylor, G. (2002). Globalization and the environment: Strategies for international voluntary environmental initiatives. Academy of Management Executive, 16(3), 121-135.

[8] Christmann, P., \& Taylor, G. (2006). Firm self-regulation through international certifiable standards: determinants of symbolic versus substantive implementation. Journal of
International Business Studies, 37(6), 863-878.

[9] Corbett, C. J., \& Kleindorfer, P. R. (2001). Environmental management and operations management: Introduction to part 1 (manufacturing and eco-logistics). Production and Operations Management, 10(2), 107-111.

[10] Colicchia, C., Marchet, G., Melacini, M., \& Perotti, S. (2013). Building environmental sustainability: empirical evidence from logistics service providers. Journal of Cleaner Production, 59, 197-209.

[11] Coyle, J. J., Bardi, E. J., \& Langley, C. J. (2003). The management of business logistics: A supply chain perspective, 7th ed. Masion, OH: South-Western/Thomson Learning.

[12] Delfmann, W., Albers, S., \& Gehring, M. (2002). The impact of electronic commerce on logistics service providers. International Journal of Physical Distribution \& Logistics Management, 32(3), 203-222.

[13] Demir, E., Bektas, T., \& Laporte, G. (2014). A review of recent research on green road freight transportation. European Journal of Operation Research, 237(3), 775-793.

[14] Etzion, D. (2007). Research on organizations and the natural environment, 1992-present: A review. Journal of Management, 33(4), 637-664.

[15] Fichman, R. G. (2004). Going beyond the dominant paradigm for information technology innovation research: emerging concepts and methods. Journal of the Association for Information Systems, 5(8), 314-355.

[16] Fiol, C. M. \& O’Connor, E. J. (2003). Waking up! Mindfulness in the face of bandwagons. Academy of Management Review, 28(1), 54-70.

[17] Fussel, L., \& Georg, S. (2000). The institutionalization of environmental concerns: making the environment perform. International Studies of Management and Organization, 30(3), 41-58.

[18] Gilley, K. M., Worrell, D. L., \& El-Jelly, A. (2000). Corporate environmental initiatives and anticipated firm performance: the differential effects of process-driven versus product-driven greening initiatives. Journal of Management, 26 (6), 199-216.

[19] Gonzalez-Benito, J., \& Gonzalez-Benito, O. (2005). An analysis of the relationship between environmental motivations and ISO 14001 Certification. British Journal of Management, 16(1), 133-148.

[20] Gonzalez-Benito, J., \& Gonzalez-Benito, O. (2006). A review of determinant factors of environmental proactivity. Business Strategy and the Environment, 15(2), 87-102.

[21] Graafland, J., \& Mazereeuw-Van der Duijn Schouten, C. (2012). Motives for corporate social responsibility. De Economist, 160(4), 377-396.

[22] Hellstrom, T. (2007). Dimensions of environmentally sustainable innovation: the structure of eco-innovation concepts. Sustainable Development, 15(3), 148-159.

[23] Henriques, I., \& Sadorsky, P. (1999). The relationship between environmental commitment and managerial perceptions of stakeholder importance. Academy of Management Journal, 42(1), 87-99. 
[24] Henriques, I., \& Sadorsky, P. (2007). Environmental technical and administrative innovations in the Canadian Manufacturing Industry. Business Strategy and the Environment, 16(2), 119-132.

[25] Ho, Y. H., \& Lin, C. Y. (2014). Mindfulness thinking in environmental management. SS International Journal of Business and Management Research, 4(6), 27-56.

[26] Husted, B. W. (2005). Culture and ecology: A cross-national study of the determinants of environmental sustainability. Management International Review, 45(3), 349-371.

[27] Inman, R. A. (2002). Implications of environmental management for operations management. Production Planning and Control, 13(1), 47-55.

[28] Jenkin, T.A., McShane, L., \& Webster, J. (2011). Green information technologies and systems: employees' perceptions of organizational practices. Business \& Society, 50(2), 266-314.

[29] Kudla, N. L., \& Klaas-Wissing, T. (2012). Sustainability in shipper-logistics service provider relationships: A tentative taxonomy based on agency theory and stimulus-response analysis. Journal of Purchasing \& Supply Management, 18(2), 218-231

[30] Langer, E. J. (1989). Mindfulness. Reading, MA: Addison Wesley.

[31] Langer, E. J. (1997). The power of mindful learning. Reading, MA: Addison Wesley.

[32] Lin, C. Y. (2011). A review of research on environmental issues in the logistics industry. Information Management \& Business Review, 3(1), 19-26.

[33] Lin, C. Y., \& Ho, Y. H. (2011). Determinants of green practice adoption for logistics companies in China. Journal of Business Ethics, 98(1), 67-83.

[34] Maas, S., Schuster, T., \& Hartmann, E. (2014). Pollution prevention and service stewardship strategies in the third-party logistics industry: Effects on firm differentiation and the moderating role of environmental communication. Business Strategy \& the Environment, 23(1), 38-55.

[35] Marchet, G., Melacini, M., \& Perotti, S. (2014). Environmental sustainability in logistics and freight transportation: A literature review and research agenda. Journal of Manufacturing Technology Management, 25(6), 775-811.

[36] McKinnon, A. (1995). Special issues on environmental aspects of logistics. International Journal of Physical Distribution and Logistics Management, 25(2), 3-4.

[37] Molla, A., \& Abareshi, A. (2012). Organizational green motivations for information technology: empirical study. Journal of Computer Information Systems, 52(3), 92-102.

[38] Murphy, P. R., \& Poist, R. F. (2000). Green logistics strategies: an analysis of usage patterns. Transportation Journal, 40(2), 5-16.

[39] Murphy, P. R., \& Poist, R. F. (2003). Green perspectives and practices: a "comparative logistics" study. Supply Chain Management: An International Journal, 8(2), 122-131.
[40] Murry, S. (2007). The green way to keep on trucking environmental technology: Transport companies are using route-planning software to reduce emissions and internet matching systems to fill empty vehicles. Financial Times, Mar 13, 12

[41] Ndubisi, N. O. (2012). Mindfulness, quality and reliability in small and large firms. International Journal of Quality \& Reliability Management, 29(6), 600-606.

[42] Nejati, M., Amran, A., \& Ahmad, N. H. (2014). Examining stakeholders' influence on environmental responsibility of micro, small and medium-sized enterprises and its outcomes. Management Decision, 52(10), 2021-2043.

[43] Oberhofer, P., \& Dieplinger, M. (2014). Sustainability in the transport and logistics sector: Lacking environmental measures. Business Strategy \& the Environment, 23(4), 236-253.

[44] Prajogo, D., Tang, A.K.Y., \& Lai, K.-H. (2014). The diffusion of environmental management system and its effect on environmental management practices. International Journal of Operations \& Production Management, 34(4), 565-585.

[45] Quazi, H. A., Khoo,Y-K., Tan, C-M., \& Wong, P-S. (2001). Motivation for ISO 14000 certification: development of a predictive model. Omega, 29(6), 525-542.

[46] Ramanathan, U., Bentley, Y., \& Pang, G. (2014). The role of collaboration in UK green supply chains: An exploratory study of the perspectives of suppliers, logistics and retailers. Journal of Cleaner Production, 70, 231-241.

[47] Ranerjee, S. B. (2011). Embedding sustainability across the organization: a critical perspective. Academy of Management Learning \& Education, 10(4), 719-731.

[48] Ray, J. L., Baker, L. T., \& Plowman, D. A. (2011). Organizational mindfulness in business schools. Academy of Management Learning \& Education, 10(2), 188-203.

[49] Russo, M. V., \& Fouts, P. A. (1997). A resource-based perspective on corporate environmental performance and profitability. Academy of Management Journal, 40(3), 534-559.

[50] Sarkis, J., Meade, L. M., \& Talluri, S. (2004). E-logistics and the natural environment. Supply Chain Management: An International Journal, 9(4), 303-312.

[51] Schultze U., \& Orlikowski W. (2004). A practice perspective on technology-mediated network relations: the use of Internet-based self-serve technologies. Information Systems Research, 15(1), 87-106.

[52] Skjoett-Larsen, T. (2000). European logistics beyond 2000. International Journal of Physical Distribution and Logistics Management, 30(5), 377-387.

[53] Sonenshein, S., DeCelles, K. A., \& Dutton, J. E. (2014). It's not easy being green: The role of self-evaluations in explaining support of environmental issues. Academy of Management Journal, 57(1), 7-37.

[54] Sternberg, R. J. (2000). Images of mindfulness. Journal of Social Issues, 56(1), 11-26.

[55] Swanson E. B., \& Ramiller, N. C. (2004). Innovating mindfully with information technology. MIS Quarterly, 
28(4), 553-583.

[56] Thai, V., Cahoon, S., \& Tran, H. T. (2011). Skill requirements for logistics professionals: findings and implications. Asia Pacific Journal of Marketing and Logistics, 23(4), 553-574.

[57] Uecker-Mercado, H., \& Walker, M. (2012). The value of environmental social responsibility to facility managers: revealing the perceptions and motives for adopting ESR. Journal of Business Ethics, 110(2), 269-284.

[58] Valorinta, M. (2009). Information technology and mindfulness in organizations. Industrial and Corporate Change, 18(5), 963-997.

[59] Wals, A. E. J., \& Schwarzin, L. (2012). Fostering organizational sustainability through dialogic interaction. Learning Organization, 19(1), 11-27.

[60] Wassmer, U., Paguin, R., \& Sharma, S. (2014). The engagement of firms in environmental collaborations: Existing contributions and future directions. Business \& Society, 53(6), 754-786.

[61] Watson, R., Boudreau, J., \& Li, S. (2010). Telematics at UPS: energy informatics in action. MIS Quarterly Executive, 9(1), 10.

[62] Weick K. E., \& Sutcliffe K. M. (2001). Managing the unexpected: assuring high performance in an age of complexity. San Francisco, CA: Jossey-Bass.

[63] Weick, K. E., \& Sutcliffe, K. M. (2006). Mindfulness and the quality of organizational attention. Organization Science, 17(4), 514-524.

[64] Wiengarten, F., Pagell, M., \& Fynes, B. (2013). ISO 14000 certification and investments in environmental supply chain management practices: identifying differences in motivation and adoption levels between Western European and North American companies. Journal of Cleaner Production, 56, 18-28.

[65] Winn, M. I., \& Angell, L. C. (2000). Towards a process model of corporate greening. Organization Studies, 21(6), $1119-1147$.

[66] Wolf, M., Beck, R., Pahlke, I. (2012). Mindfully resisting the bandwagon: reconceptualising IT innovation assimilation in high turbulent environments. Journal of Information Technology, 27(3), 213-235.

[67] Wu, H-J., \& Dunn, S. C. (1995). Environmentally responsible logistics systems. International Journal of Physical Distribution and Logistics Management, 25(2), 20-38. 